\title{
CONFERENCIA
}

\section{ASPECTO MORFOLÓGICO Y MOLECULAR DEL DESARROLLO DE LAS VELLOSIDADES CORIÓNICAS HUMANAS EN PLACENTAS NORMALES Y PATOLÓGICAS}

\author{
Daniela MARZIONI, Teresa LORENZI, Caterina CRESCIMANNO y Mario CASTELLUCCI \\ Departamento de Patología Molecular y Terapias Innovativas, Universidad Politécnica de la Marcha, \\ Ancona, Italia.
}

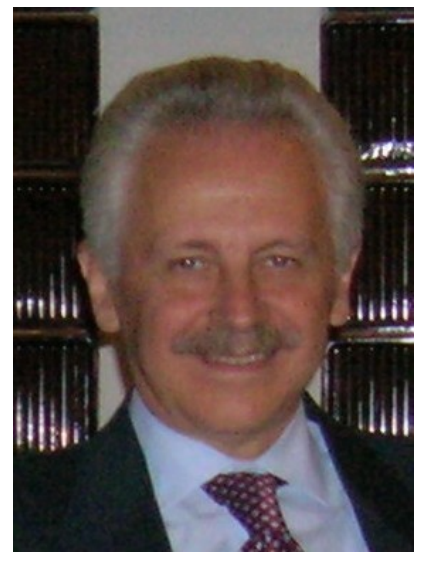

Un número creciente de embarazos se complican por inexplicable desarrollo anormal del arbol de vellosidades placentarias. El crecimiento y desarrollo de las vellosidades son pasos importantes en la morfogénesis de la placenta. Durante la gestación se forman cinco tipos diferentes de vellosidades: vellosidad mesenquimal, vellosidades intermedias inmadura y madura, vellosidades originarias y terminales. Centramos nuestra atención en los eventos estructurales del crecimiento temprano para la formación de las vellosidades mesenquimales. Las otras son formaciones nuevas, en continuo crecimiento, de zonas calientes y brotes trofoblásticos. Por esta razón, existen en todas las etapas del embarazo y tienen que ser consideradas como básicas para el crecimiento y diferenciación del árbol velloso. En los dos primeros trimestres son precursoras de las vellosidades inmaduras intermedias, mientras que en el último trimestre las vellosidades mesenquimales se transforman en intermedias maduras. Las vellosidades intermedias inmaduras formadas durante los primeros trimestres son etapas del desarrollo hacia las vellosidades primarias. Otra forma importante de crecimiento y diferenciación placentaria está orientada hacia las células insulares y columnares. Estas dos estructuras representan centros de proliferación trofoblástica situados en la periferia del árbol velloso sosteniendo su crecimiento. También hemos analizado el rol de varias moléculas de la matriz extracelular (p/ej.: tenascina, proteoglicano de heparán sulfato, ácido hialurónico), varios factores de crecimiento y sus receptores (p/ej.: factor de crecimiento fibroblástico básico, receptor del factor de crecimiento epidérmico) al igual que proteínas como HtrA1 en la diferenciación vellosa y la morfogénesis placentaria. Estas moléculas también han sido estudiadas en patología placentaria. Cuando el trofoblasto escapa de los mecanismos de control del crecimiento normal que están presentes durante el embarazo normal, se podrán desarrollar enfermedades gestacionales trofoblásticas con diversos grados de malignidad, tales como mola hidatidiforme y coriocarcinoma. Nuestros estudios muestran que el desarrollo fisiológico del árbol velloso placentario se debe a un delicado balance del patrón molecular involucrado en los procesos morfogénicos fundamentales y cuando el balance se rompe, pueden desarrollarse patologías. 